\title{
The Victorian Society's Fear of the New Woman in Bram
}

Asst. Inst. Haneen Sabah Abid: h.alibrahim@yahoo.com

Al Ma'moun University College, Department of English Language

(Received on 22/4/2018: Accepted on 3/6/2018)

\begin{abstract}
Nineteenth century Gothic literature was deeply concerned with the threats against masculinity. Perhaps one of the most important changes that happened at that time was the emergence of the New Woman model which posed a great threat against masculinity and the male role in the Victorian society. Bram Stoker's Dracula (1897) portrays female characters who embody this transition in female roles from the domestic wife to the New Woman. This paper focuses on the female characters Mina Murray and Lucy Westenra, their roles in their society, and the different fates they face at the end of the novel, with special focus on Mina's transformation to the model of the New Woman.
\end{abstract}

Key words: Dracula, New Woman, Feminism, Victorian, Society. 
Bram Stoker's novel Dracula was published in 1897, an era which brought with it the idea of a powerful woman, the "New Woman", a woman who desires to be educated, as well as sexually and economically liberated. The novel is full of themes of feminism and the ideals of Victorian women; it centers around two different kinds of women in a male-dominated Victorian society. Both kinds undergo hardships and repressions by men, yet each one of them faces a different fate. On one hand, Stoker creates his male characters in the novel as being well gentlemen with good deeds and morality. Even Count Dracula, the only evil man in the novel, is described as being well educated and enjoying a sense of good hospitality for his guests. The only danger they face is that of women's sexuality and its control over their reason, but they do not seem to fall for them completely and they succeed in repressing their sexuality and returning the changed women to purity, while saving the ones who did not change.

On the other hand, Stoker creates two groups of women, the one that consists of Mina Murray and Lucy Westenra who are well known for their purity, loyalty for their men, and the virtuous and respectable characteristics of the ideal Victorian woman they have. The other group consists of the three beautiful vampire women who are imprisoned in Castle Dracula and suffer from his evilness by turning them into undead creatures hungry for blood and physical pleasures, and they surely do not represent the image of an ideal woman. They are rather the embodiment of the male's imagination that cannot be found in a Victorian woman because of the boundaries of sexuality that the society imposed on her. So they are rather the fallen women who try to trap men with them and cause them to fall from grace and compromise their social position.

Stoker's novel Dracula is one of the novels in the Victorian age that deals with the victimization of women and their oppression in the male 
society which tries to keep them in hiding, either for their own pleasure or for realizing the women's sexuality and its danger upon men. This paper studies Stoker's treatment of the women in this novel, with the focus on Mina Murray's embodiment of the figure of the New Woman, and Lucy Westenra's fall from grace in a society that was becoming less and less Victorian.

The first thing to notice in the novel is the kinds of relationships between the male and female characters. Phyllis A. Roth states that "only relations with vampires are sexualized in this novel; indeed, a deliberate attempt is made to make sexuality seem unthinkable in 'normal relations' between the sexes" ${ }^{1}$, while the relationships between Mina and her husband, or Lucy and the three suitors are more elevated and spiritual. This is an attempt of Stoker to emphasize on the significance of virtue in women and how they are viewed by society if they were more like the vampiresvoluptuous, aggressive, and repulsive.

A woman in the Victorian time had the option to be either a virgin, thus becoming a model of purity; or a wife and a mother, a position that renders her to the domestic selfless life where she puts the priorities of others before hers. Both Mina and Lucy are introduced to the novel as pure and chaste women who are far away from the evilness and impurity they are going to encounter later on by the hands of Count Dracula. But the difference between these two women here is that Mina transforms throughout the novel to this figure of the pure and chaste wife who devotes herself to helping her husband and Van Helsing's men to destroy Count Dracula. While Lucy falls a victim mostly because of her physical beauty and open sexual desires that render her impure in the eyes of society and turns her into a thing rather than a human being. Therefore, killing her later is the only chance and best 
solution to restore her soul and return her to a purer state that the society can accept for women.

Another difference we find between Mina and Lucy is their opinions of motherhood and their acceptance or refusal of the role of motherhood. The traditional woman had to be a mother and she had to embrace her domestic role of being a loyal wife and a caring mother. If she did not accept this role, then she must be punished somehow. Stoker gives us two contradictory groups of women, one groups is that of the three vampire sisters and Lucy who refuse motherhood, and the other group is that of Mina who embraces motherhood. On this matter, Stephanie Demetrakopoulous states that "Stoker's vampire women not only reject motherhood, they dine on children"2. So, by eating children, the vampires and Lucy demonstrate their rejection of motherhood, a traditional and natural role for women. The vampire sisters appear in one scene eating a live baby given to them by Dracula himself to sate their hunger. While Lucy's transformation to a vampire is announced by a newspaper clip declaring seeing "a bloofer lady" eating a child. Stoker suggests that she feeds on a baby like an animal "With a careless motion, she flung to the ground, callous as a devil, the child that up to now she had clutched strenuously to her breast, growling over it as a dog growls over a bone." (225). Demetrakopoulous also adds that "the vampire women are outlaws of society through their utter rejection of the conventional feminine role." ${ }^{3}$ Therefore, by rejecting the natural role of a mother, the vampire sisters and Lucy become an inversion of the ideal Victorian woman, thus; they had to be punished.

However, the men's decision to destroy Lucy is not empty of selfish concerns. Men were afraid for their own safety, and the female sexuality was one of the biggest dangers that threatened them and shook their position in society. Such women with awareness of their own desires were socially 
scorned; therefore, the men did not want to associate with them, and destroying them was the best, or probably the only thing to do in order to save themselves from such kind of danger.

Women were thought of as being objects in a household that belongs to the man only, and thus they can not function or act by themselves as free and independent individuals. Lucy, like Mina, is the embodiment of the typical and ideal Victorian woman at the beginning of the novel, but she changes after she is being bitten by Count Dracula. She becomes unable to participate in almost any daily activity, and turns restless and tends to live the domestic life. And by this she becomes the victim of man's cruelty and selfishness represented by the Count who makes her a vampire and keeps her for his own purposes of reproduction. Therefore, she becomes the representation of the domestic helpless woman, unlike Mina who symbolizes the New Woman in her actions and independence even when being married.

Moreover, Mina represents the break from the image of the old woman to the new woman. She is considered the novel's heroine in many ways- she is a practical woman who works as an assistant schoolmistress, which shows her independence and her realization of the importance of such independence. She maintains purity and innocence even though she suffers from Count Dracula's evilness later in the novel. She plays a major role in leading Van Helsing and his crew to Dracula and killing him. Mina also realizes her role in society and decides to learn how to use typewriters and shorthand in order to be helpful for her husband in the future. Mina keeps progressing throughout the novel and keeps her own journal or diary which emphasizes the significance of writing by women even if for personal matters. Geoffrey Wall remarks on Mina that "She is the rewriter, the transcriber, the secretary who arranges all the documents in chronological 
order and composes the case (legal and medical) of Dracula. She acquires an enormous structural importance as the-woman-who-writes." 4

In realizing the importance of writing for her, she keeps a journal as a practice and tries to write about things that happen, facts and accounts to make them more realistic, and also to maintain her own freedom through her writing because in this journal she is probably more capable of expressing her feelings and giving her personal accounts about the events surrounding her than talking them out to the male environment around her. Kathryn Boyd describes Mina as "simultaneously knowledgeable and curious about the world around her", "peppered with historical and literary references, legal terms, and applications of contemporary scientific theory." This, in fact, suggests that she is thirsty for knowledge, and this thirst gives her strength and independence. Even though women were not fully given roles and importance in their society, Van Helsing acknowledges Mina's importance and virtues by stating that "She is one of God's women, fashioned by His own hand to show us men and other women that there is a heaven where we can enter, and that its light can be here on earth. So true, so sweet, so noble, so little an egoist"

When Count Dracula mocks Van Helsing and his men later in the novel by saying "your girls that you all love are mine already; and through them you and others shall yet be mine" (251), he emphasizes on women's desires that he brings to the surface by turning them into vampires, which in turn evokes men's fear for their own safety because women would become the reason for their fall from grace. Count Dracula here intends on destroying his enemies through corrupting the women they know and turning them into monsters filled with oppressed desires and ready to seduce their men to fulfill those desires. Count Dracula chooses Lucy as his first victim in the 
novel because she is weaker than Mina, connected with three of Dracula's enemies, and aware of her physical attractiveness and kept desires. She laments in a letter to Mina her inability to marry more than one man in her life when she says "Why can't they let a girl marry three men, or as many as want her" (67). She is sexualized throughout the novel, which makes her an easier target for Count Dracula rather than Mina who seems more spiritualized and capable of surviving in the world of men. Lucy seems more aware of her desires and she expresses her wish of fulfilling them, but she soon retreats from her thoughts and calls them "heresy" knowing what the society's judgment would be upon her if her desires are revealed.

It becomes obvious from Jonathan Harker's journal in chapter three that the three vampire sisters have some kind of control over him at the beginning. He describes them in an almost pornographic way that indicates his appeal to them and his desires of having them kiss him. He states:

All three had brilliant white teeth, that shone like pearls against the ruby of their voluptuous lips. There was something about them that made me uneasy, some longing and at the same time some deadly fear. I felt in my heart a wicked, burning desire that they would kiss me with those red lips. (61)

The danger of this appeal lies in his desire of having an experience with such women in his life, but he senses at the same time the wickedness and intimidation that looms around his self-control with such women. Carol A. Senf suggests that this particular passage "emphasizes the fearful and repulsive aspects of the sexual relationship itself." In the Victorian society, such women are just the subject of the male's fantasy, while the socially accepted woman is virtuous and has domestic and pure characteristics. And that's why the three vampire sisters attracted Jonathan with their acts, 
because they represent part of his fantasy that cannot be fulfilled or experienced with Mina. They exemplify both the dream and the nightmare for the male-dominated society. Senf adds that in Harker's mind "the voluptuous woman is transformed into a carnivorous animal and finally he reduces her to a mouth filled with sharp white teeth." ${ }^{8}$ These vampirewomen are in no way similar to Mina or Lucy before her transformation. While the living women are virtuous and chaste, those three vampires are aggressive, evil, and dangerous with their sexuality. They have been kept victims by Count Dracula for long time that they turned into these undead creatures with no hope of restoring them to purity.

Later in the novel we see Count Dracula's threat to his enemies coming into action through the now-changed Lucy. Count Dracula is trying to destroy his enemies through Lucy's attempts to lure her fiancé, Arthur Holmwood, and affecting him by her voice and promises of pleasure that seem to affect not just Arthur but everyone else who hears it. Her hunger for blood and physical pleasure seems strong enough to tempt men to leave their reason and risk their position in society, safety, and eventually their lives. Dr. John Seward writes in his journal in chapter sixteen of the novel that "There is something diabolically sweet in her tones -something of the tingling of glass when struck -which rang through the brains even of us who heard the words addressed to another. As for Arthur, he seemed under a spell; moving his hands from his face, he opened wide his arms." (219) She becomes a dangerous figure who is trying to destroy men with her lustful appeal.

Lucy's transformation to a monstrous vampire and an undead thing reinforces her sexual danger and her desires that can not be fulfilled in the Victorian society. She changes into a creature that tries to tempt men and make them fall for her demonic spell by embodying their fantasy. Thus, 
according to the Victorian society, such monstrous creature should be eliminated. But her death is rest for her as well as other women, not just for the men in the novel. And by her death, her soul is returned to her body and to heaven where she is no more a threat of sexuality. And with this, she also maintains a look of purity that is suitable for all Victorian women.

Stoker describes the scene in which Lucy is killed by her fiancé very sexually which represents her unfulfilled and repressed desire as a woman in the Victorian time. Her end by the hand of men could be read as the male's society domination over women and repressing their kept desires eternally, which in turn reinforces men's self control and reason against the dangerous female's sexuality. Or it could also be read as the emancipation of women from their repression and their final peace and freedom.

Lucy is freed from the power and spell of Count Dracula that made her a victim for his own pleasures and revenge. But before Lucy has been emancipated from Count Dracula's victimization of her, she is dehumanized and denied her human identity by calling her "the Thing" instead of "Lucy". Her killing is described as being merciful for men and significant for the survival of the male as well. Death seemed the only cure for Lucy's condemnation, and by killing her, she is not only emancipated from Dracula's evil, but men's unity and safety is maintained at the same time. The vampire Lucy characterizes the repressed sexual desires of the female that creates danger and evil around the men, and when she is dead her evil is gone and males are safe.

The novel asserts on the importance of women's purity and how they should not behave, otherwise would be despised by their society. Dr. Seward portrays Lucy in her tomb when they go to kill her as a "devilish mockery of Lucy's sweet purity" (221). Even though Dr. Seward loves Lucy and is sad for her rejection of his marriage proposal, his love for her turns into disgust 
at the image of the vampire she became lying in the coffin. So women are not loved once they lose their purity and innocence. Stoker portrays the vampire Lucy with all the appalling and almost pornographic features, yet her peaceful and pure traits are returned to her after her death as Dr. Seward states again in his journal:

There, in the coffin lay no longer the foul Thing that we had so dreaded and grown to hate that the work of her destruction was yielded as a privilege to the one best entitled to it, but Lucy as we had seen her in her life, with her face of unequalled sweetness and purity... One and all we felt that the holy calm that lay like sunshine over the waster face and form was only an earthly token and symbol of the calm that was to reign for ever. (224)

Mina, on the other side, proves herself to be self-sufficient and independent woman. At some point in the novel, she explains that she never knew her parents. So this makes her gain her independence at an early age. Boyd explains that "The fact that Mina had no parents (and therefore no providers) would have been socially and economically significant in her time, and it also allows her to fit neatly into the trope of the archetypal orphaned hero" ". Having lived without parents at a young age makes her a stronger character. She is professional, independent, and willing to fight Dracula just like the male characters around her. So this, in a way, makes her equal to them. Yet, at the same time, she doesn't completely break from the social norms of her society. The only thing that probably stands in Mina's way from completely embodying the vivid image of the New Woman is her willingness to stay by her husband's side and serving him with the best she can. She already is a schoolmistress; she writes and is trying to learn new 
and helpful skills. But she wants to use these skills in helping her husband in the future not to break from him. However, her virtue and loyalty to the men in her world elevates her to a level that makes the male characters in the novel acknowledge and appreciate her essential role as a graceful woman in saving the world from evilness. Therefore, she is towards becoming a new woman without sacrificing her domestic life.

Thus, Stoker ends his novel in a more classical way which was suitable for his time through making his character choose marriage and domestic life over the newly claimed, yet still rejected, independence. Mina, the woman who helps Van Helsing's crew in their hunt of Dracula by her job of collecting the journals and evidences against him is suddenly excluded from the group of men and is put back forcefully to the domestic life. Although they acknowledge the importance of her job in helping them kill Count Dracula, they no longer want her to be part of their team, and they also do not want her to participate in killing Dracula because it is a very masculine task to do and if she does it then she will lose her purity and femininity and be transformed into a "thing" like Lucy, rather than a human being. On this, Jonathan writes in his journal at the beginning of chapter nineteenth:

I am glad that she [Mina] consented to hold back and let us men do the work. Somehow, it was a dread to me that she was in this fearful business at all; but now that her work is done, and that it is due to her energy and brains and foresight that the whole story is put together in such a way that every point tells, she may well feel that her part is finished, and that she can henceforth leave the rest to us (252).

However, we can see here that although Mina has been excluded from the team, they still acknowledge her significant role in helping the men 
kill Dracula. So, this can be considered as an achievement in itself for Mina, because her work has been recognized by the men in her society. Therefore, Mina can be the embodiment of the New Woman in the future. She symbolizes both leader and mother figure, so she takes both domestic and independent roles for women. She leads the men to Dracula through her outstanding work; and when this part is finished, she returns to her domestic life and chooses to become a wife and a mother.

In conclusion, it is very interesting to notice how Stoker addresses society's fear of the idea of the New Woman through the character of Mina. she seems to dare the patriarchal chain and become equal to the male characters in her society for she is the reason for killing Count Dracula. What makes her defy the traditional or patriarchal definition of women is the fact that she is not killed by the end of the novel. On the contrary, we see her return home to her life and become a dutiful wife. Eric Kwan-Wai Yu asserts that "Stoker is much ahead of his times in portraying a "New Woman" surpassing even the best male 'professionals' in terms of intellectual labors" 10 , and he describes her as a "'gallant' woman with a remarkable 'man-brain'" . Thus, she defies the traditional definition of the domestic woman because she is not punished or sacrificed, and because she intellectually powerful and equal to the men in her life.

\section{Notes}

${ }^{1}$ Phyllis A. Roth "Suddenly Sexual Women in Bram Stoker's Dracula". Bram Stoker's Dracula. Ed. Harold Bloom. Philadelphia: Chelsea House Publishers, 2003. (6)

${ }^{2}$ Demetrakopoulous, Stephanie. "Feminism, Sex Role Exchanges, and Other Subliminal Fantasies in Bram Stoker's Dracula". Frontiers: A Journal of Women Studies, Vol. 2, No. 3. (Autumn, 1977), pp. 104-113. (107). 
${ }^{3}$ Ibid (107).

${ }^{4}$ Wall, Geoffrey. "'Different from Writing': Dracula is 1897" Bram Stoker's Dracula. Ed. Harold Bloom. Philadelphia: Chelsea House Publishers, 2003. 27-37. (29).

${ }^{5}$ Kathryn Boyd. Making Sense of Mina: Stoker's Vampirization of the Victorian Woman in Dracula. MA Thesis. Trinity University, 2014. (13-14).

${ }^{6}$ Stoker, Bram. Dracula: Complete, Authoritative Text with Biographical, Historical and Cultural Contexts, Critical History, and Essays from Contemporary Critical Perspectives. New York: Palgrave, 2002. (198).

All references to the novel are made to this edition and page number is given parenthetically.

7 Carol A. Senf. “'Dracula': Stoker's Response to the New Woman." Victorian Studies, Vol 26, No. 1. Indiana: Indiana University Press, 1982. (41).

${ }^{8} \operatorname{Ibid}(41)$.

9 Kathryn Boyd. Making Sense of Mina: Stoker's Vampirization of the Victorian Woman in Dracula. MA Thesis. Trinity University, 2014. (29)

${ }^{10} \mathrm{Yu}$, Eric Kwan-Wai. "Productive Fear: Labor, Sexuality, and Mimicry in Bram Stoker's Dracula". Texas Studies in Literature and Language, 2006 Summer; 48 (2): 145-70. (158).

${ }^{11}$ Ibid (158). 


\section{References}

1. Boyd, Kathryn. Making Sense of Mina: Stoker's Vampirization of the Victorian Women in Dracula. MA Thesis. Trinity University, 2014.

2. Demetrakopoulous, Stephanie. "Feminism, Sex Role Exchanges, and Other Subliminal Fantasies in Bram Stoker's Dracula". Frontiers: A Journal of Women Studies, Vol. 2, No. 3. (Autumn, 1977): pp. 104113.

3. Roth, Phyllis A. "Suddenly Sexual Women in Bram Stoker's Dracula". Bram Stoker's Dracula. Ed. Harold Bloom. Philadelphia: Chelsea House Publishers, 2003. 3-14.

4. Senf, Carol A. "'Dracula': Stoker's Response to the New Woman" Victorian Studies, Vol 26. No. 1 (1982), pp. 33-49.

5. Stoker, Bram. Dracula: Complete, Authoritative Text with Biographical, Historical and Cultural Contexts, Critical History, and Essays from Contemporary Critical Perspectives. New York: Palgrave, 2002.

6. Wall, Geoffrey. "'Different from Writing': Dracula is 1897” Bram Stoker's Dracula. Ed. Harold Bloom. Philadelphia: Chelsea House Publishers, 2003. 27-37.

7. Yu, Eric Kwan-Wai. "Productive Fear: Labor, Sexuality, and Mimicry in Bram Stoker's Dracula". Texas Studies in Literature and Language, 2006 Summer; 48 (2): 145-70.

\footnotetext{
خوف المجتمع الفكتوري من المرأة الجديدة في رواية (-راكولا) لبرام ستوكر
} 


\section{م.م م م منين صباح عبد \\ كلية الملمون الجامعة / قسم اللغة الانكليزية}

كان ادب القرن التاسع عشر القوطي مهتما بالتهديد ضد الرجولة. أن احدى أهم

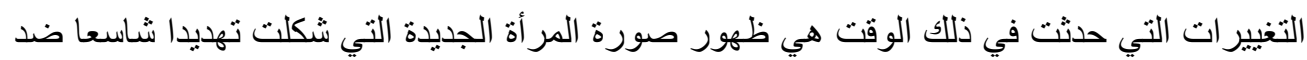
الرجولة, و دور الرجل في المجتمع الفكتوري. صورت رواية برام ستوكر دراكولا التي نشرت في

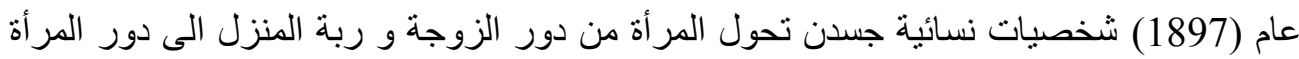
الجديدة. بركز هذا البحث على دور كل من شخصية مينا موراي و لوسي ويستينر ا في المجتمع، و الأقار المختلفة التي واجهتاها في نهاية الرواية، لا سيما تحول شخصية مينا الى هيأة المر أة الجديدة. كلمات مفتاحية: در اكو لا, المر أة الجديدة, الحركة النسوية, فكتوري, مجتمع.

About the Author:

Haneen Sabah Abid Al Ibrahim is an assistant lecturer at Al-Ma'moon University College, Department of English. She holds a Masters degree in English Literature from Indiana University of Pennsylvania in the United States, and is a Fulbright Scholarship Program Alumna.

Email: h.alibrahim@yahoo.com 